\title{
Horizontal spread of mer operons among Gram-positive bacteria in natural environments
}

\author{
E. S. Bogdanova, ${ }^{1}$ I. A. Bass, ${ }^{1}$ L. S. Minakhin, ${ }^{1}$ M. A. Petrova, ${ }^{1,2}$ \\ S. Z. Mindlin, ${ }^{1}$ A. A. Volodin, ${ }^{1}$ E. S. Kalyaeva, ${ }^{1}$ J. M. Tiedje, ${ }^{2}$ \\ J. L. Hobman, ${ }^{3}$ N. L. Brown ${ }^{3}$ and V. G. Nikiforov ${ }^{1}$
}

\begin{abstract}
Author for correspondence: E. S. Bogdanova. Tel: +795 1960208. Fax: +7951960221. e-mail: bogdes@img.ras.ru
\end{abstract}

\footnotetext{
1 Institute of Molecular Genetics, Russian Academy of Sciences, Moscow 123182, Russia

2 Center of Microbial Ecology, Michigan State University, East Lansing, MI, USA

3 School of Biological Sciences, The University of Birmingham, Edgbaston, Birmingham B15 2TT, UK
}

\begin{abstract}
Horizontal dissemination of the genes responsible for resistance to toxic pollutants may play a key role in the adaptation of bacterial populations to environmental contaminants. However, the frequency and extent of gene dissemination in natural environments is not known. A natural horizontal spread of two distinct mercury resistance (mer) operon variants, which occurred amongst diverse Bacillus and related species over wide geographical areas, is reported. One mer variant encodes a mercuric reductase with a single $\mathbf{N}$-terminal domain, whilst the other encodes a reductase with a duplicated $\mathbf{N}$ terminal domain. The strains containing the former mer operon types are sensitive to organomercurials, and are most common in the terrestrial mercury-resistant Bacillus populations studied in this work. The strains containing the latter operon types are resistant to organomercurials, and dominate in a Minamata Bay mercury-resistant Bacillus population, previously described in the literature. At least three distinct transposons (related to a class II vancomycin-resistance transposon, Tn1546, from a clinical Enterococcus strain) and conjugative plasmids are implicated as mediators of the spread of these mer operons.
\end{abstract}

Keywords: mer operon, horizontal gene transfer, Bacillus, Enterococcus, Tn1546, class II transposons

\section{INTRODUCTION}

Mercury resistance $\left(\mathrm{Hg}^{\mathrm{R}}\right)$ in both clinical and environmental isolates of bacteria has been widely reported (Nakahara et al., 1977; Gilbert \& Summers, 1988; Olson et al., 1989; for reviews see Robinson \& Tuovinen, 1984; Gadd, 1990). Mercury resistance operons (mer) have been characterized (Misra, 1992; Hobman \& Brown, 1997). Because the nucleotide

\footnotetext{
Abbreviations: MR, mercuric reductase; PMA, phenylmercuric acetate.

The EMBL accession numbers for the nucleotide sequences of mer operons and their flanking regions reported in this paper are: PKLH3, X99457 and Y08064; pKLH301, Y09027, Y10104 and Y10105; PKLH302, Y09024; pKLH304, Y09907; B. cereus RC607 mer operon flanking region, Y08065. The EMBL accession numbers for the nucleotide sequences of the internal regions of the 165 rRNA genes are: Exiguobacterium TC38-2b, Y15051; Bacillus sphaericus FA8-2, Y15045; B. cereus TA32-5, Y15050; B. cereus RC607, Y15048; B. cereus CH70-2, Y15046; B. cereus VKM684, Y15053.
}

sequences of at least 11 mer operons from different bacteria are known (see reviews by Summers, 1986; Silver \& Phung, 1996; Hobman \& Brown, 1997; Osborn et al., 1997), $\mathrm{Hg}^{\mathrm{R}}$ provides an excellent model system for studying horizontal gene transfer in the environment. Narrow-spectrum mer operons confer resistance to inorganic mercury salts: they encode a mercuryresponsive regulatory protein (MerR), one or more mercury-transport proteins, and the enzyme mercuric reductase (MR). MR (encoded by the merA gene) reduces divalent mercury $\left(\mathrm{Hg}^{\mathrm{II}}\right)$ to the relatively nontoxic metallic mercury $\left(\mathrm{Hg}^{0}\right)$ in an NADPH-dependent reaction. Broad-spectrum mer operons confer resistance to organomercurials (for example, phenylmercuric acetate, PMA) as well as inorganic mercury (Brown et al., $1989)$ and contain an additional gene $(\operatorname{mer} B)$ encoding the enzyme organomercurial lyase, which catalyses the cleavage of the $\mathrm{C}-\mathrm{Hg}$ bond of many organomercurials (Begley et al., 1986). 
With a few possible exceptions (Shiratori et al., 1989; Kholodii et al., 1993b, 1997), mer operons from Gramnegative bacteria have been found on plasmids. There is little evidence for plasmid-borne mer operons in Grampositive bacteria isolated from the environment (Belliveau \& Trevors, 1990) and several papers report the apparent chromosomal location of such mer operons (Witte et al., 1986; Mahler et al., 1986; Wang et al., 1987; Nakamura \& Silver, 1994). In Gram-negative bacteria, mer operons have often been found on transposons, many of which are class II (Tn3 family) transposons of the Tn21 sub-group (for a review see Grinsted et al., 1990) or the recently discovered transposons Tn5041 (Kholodii et al., 1997) and Tn5053 (Hobman et al., 1994; Kholodii et al., 1993b, 1995). The association of mer operons with transposons has not been reported for Gram-positive bacteria, though Siemieniak et al. (1990) have reported the nucleotide sequence of a Tn3-related class II transposon, Tn4556, from Streptomyces fradiae. This transposon contained ORFs that had a low shared identity $(30-40 \%)$ with bacterial mercuric reductases, but did not confer $\mathrm{Hg}^{\mathrm{R}}$ on the host organism.

Recent studies demonstrate considerable diversity in Gram-negative bacterial mer operons at the DNA sequence level (Kholodii et al., 1993a, 1995; Osborn et al., 1995, 1996; Yurieva et al., 1997; Liebert et al., 1997), but at the same time there is evidence of a wide geographical distribution of the same sequences. The geographical spread of mer operons has been accompanied by horizontal transfer between different bacterial genera (Yurieva et al., 1997). Diversity and dissemination of mer operons in Gram-positive bacteria has been less thoroughly studied (Hobman \& Brown, 1997; Osborn et al., 1997). Three different mer operons have been sequenced from Gram-positive bacteria: Staphylococcus aureus plasmid pI258 (Laddaga et al., 1987), Bacillus sp. RC607 (Wang et al., 1989), and Streptomyces lividans 1326 (Sedlmeier \& Altenbuchner, 1992). All of the mer operons contained mercuric ion transport genes showing little similarity to Gram-negative transport genes, and merA genes homologous to Gramnegative merA genes. The Streptomyces MR lacked the $\mathrm{N}$-terminal domain characteristic of MRs from Gramnegative bacteria. This domain (homologous to the $\mathrm{Hg}^{2+}$-binding protein MerP and dispensable for in vitro enzyme activity) is thought to have functional significance in natural environments (Silver \& Phung, 1996). The staphylococcal MR contained a single N-terminal domain, whilst the Bacillus RC607 MR contained a longer duplicated domain. Using immunological methods, we have previously identified at least five distinct subtypes of MRs in Bacillus and related strains isolated from terrestrial samples from different parts of the former Soviet Union (Bogdanova et al., 1988). Trypsin cleavage experiments demonstrated that only three strains contained MRs with a long N-terminal domain while the remaining 22 strains tested contained MRs with the short N-terminal domain (Bogdanova \& Mindlin, 1989, 1991; E. Bogdanova \& S. Mindlin, unpublished results). Nakamura \& Silver (1994) reported surprisingly low diversity of mer operons among 78 mercury-resistant Bacillus strains isolated from sediments from Minamata Bay, Japan, the site of a severe human methylmercury poisoning epidemic. All of these strains contained apparently chromosomally located broad spectrum mer operons encoding MRs with the duplicated N-terminal domain. Most of the strains contained mer operons showing restriction maps that were identical, or closely related, to that of the Bacillus sp. RC607 mer operon isolated from Boston Harbor, USA.

Here we confirm by DNA sequence analysis the considerable diversity of mer operons in terrestrial Bacillus strains suggested by our earlier immunological studies. We demonstrate that wide geographical spread and horizontal transfer of distinct mer operon variants has occurred amongst Bacillus species in the natural environment. We report DNA sequences characteristic of class II transposons at the ends of the mer operons studied. This is the first clear indication of the involvement of class II transposons in dissemination of mercury resistance in Gram-positive bacteria.

\section{METHODS}

Bacterial strains and plasmids. The strains used in this study are shown in Table 1. Most of these are from our collection of $\mathrm{Hg}^{\mathrm{R}}$ low $\mathrm{G}+\mathrm{C}$ content Gram-positive bacteria (mainly Bacillus spp.), which originally included 14 terrestrial strains from the Kamchatka peninsula, three strains from the Kuril islands, one strain from Central Asia, one strain from the Moscow region and six strains from Carpathia (Ukraine) (Bogdanova et al., 1989; Bogdanova \& Mindlin, 1991). The strains were collected with the aim that each geographical locale should represent a maximum species diversity, and strains which were identical by morphological and physiological criteria were therefore not duplicated. The strains were collected between 1985 and 1987. The freshly isolated strains were at that time preserved for long term storage using two methods: by freeze drying and under a layer of mineral oil. Stock cultures were maintained at $4-8{ }^{\circ} \mathrm{C}$ on Luria-Bertani (LB) agar with $5-7 \mu \mathrm{g} \mathrm{HgCl}_{2} \mathrm{ml}^{-1}$. In mating experiments, we used the $\mathrm{Hg}^{\mathrm{s}}$ derivative of strain TC38-2b (Bogdanova \& Mindlin, 1989). In this work we constructed its spontaneous mutant, VKM382-2 $\left(\mathrm{Rif}^{\mathrm{R}} \mathrm{Str}^{\mathbf{R}}\right)$, which was resistant to $30 \mu \mathrm{g}$ rifampicin $\mathrm{ml}^{-1}$ and $100 \mu \mathrm{g}$ streptomycin $\mathrm{ml}^{-1}$ on LB agar. The cloning vectors pACYC184, pUC19, pTZ18 and pTZ19 were used. The mer operon recombinant clones (Table 2) were obtained by standard methods (Sambrook et al., 1989) using LB agar plates supplemented with the appropriate selective agents at the following concentrations $\left(\mu \mathrm{g} \mathrm{ml}^{-1}\right)$ : ampicillin, 200 ; tetracycline, 20; chloramphenicol, $50 ; \mathrm{HgCl}_{2}, 10$.

Bacteria were identified both according to the taxonomic scheme of Bergey's Manual (Claus \& Berkely, 1986) and by determination of the nucleotide sequence of region 343-709 of the $16 \mathrm{~S}$ rRNA gene. The $16 \mathrm{~S}$ rRNA gene was amplified from genomic DNA by PCR with the forward primer BCF1, described by Cano et al. (1994), and the reverse primer $5^{\prime}$ ACATCTCTACGCATTTCACC $3^{\prime}$ (this work) and cloned into a plasmid vector using the TA cloning kit (Invitrogen) according to the manufacturer's instructions. The $16 \mathrm{~S}$ rRNA fragment was sequenced in both directions from the vector primers SP6 and T7. The FA8-2 and TC47-5 16S rRNA gene 
Table 1. Characteristics of strains and mer operons

\begin{tabular}{|c|c|c|c|c|c|c|c|c|c|}
\hline \multicolumn{2}{|c|}{ Strain } & \multirow[t]{2}{*}{ Source* } & \multicolumn{3}{|c|}{ Hybridization with probes $\dagger$} & \multirow{2}{*}{$\begin{array}{l}\text { Location of } \\
\text { mer operon }\end{array}$} & \multirow{2}{*}{$\begin{array}{c}\text { Resistance to } \\
\text { PMA }\end{array}$} & \multicolumn{2}{|c|}{ Mercuric reductase } \\
\hline & & & $\begin{array}{c}\text { pKLH3.2 } \\
\text { merR, ORFs }\end{array}$ & $\begin{array}{c}\text { pKLH3.3 } \\
\text { mer } A\end{array}$ & $\begin{array}{c}\text { pKLH3.4 } \\
\text { merB }\end{array}$ & & & $\begin{array}{l}\text { N-terminal } \\
\text { domain }\}\end{array}$ & $\begin{array}{c}\text { Immunologica } \\
\text { subtype } \|\end{array}$ \\
\hline 1 & Bacillus sphaericus FA8-2 & 1 & $+(9 \cdot 5 \mathrm{~kb})$ & $+(9.5 \mathrm{~kb})$ & - & pKLH301 & $0.1(5)$ & Short & II-1 \\
\hline 2 & B. cereus TA32-5 & 1 & $+(\sim 15 \mathrm{~kb})$ & $+(\sim 15 \mathrm{~kb})$ & - & pKLH302 & $<0 \cdot 1-0 \cdot 1(7)$ & Short & II-1 \\
\hline 3 & B. cereus $\mathrm{CH} 70-2$ & 2 & $+(\sim 15 \mathrm{~kb})$ & $+(\sim 15 \mathrm{~kb})$ & - & pKLH303 & $0 \cdot 1(2)$ & Short & II-1 \\
\hline 4 & Unidentified TA32-12 & 1 & $+(7$ and $8 \mathrm{~kb})$ & $+(7$ and $8 \mathrm{~kb})$ & - & Chromosome & $<0.1-0.1(2)$ & Short & II-1 \\
\hline 5 & B. licheniformis FA6-12 & 1 & $+(3 \cdot 2 \mathrm{~kb})$ & $+(3 \cdot 2 \mathrm{~kb})$ & - & Chromosome & $0.1(3)$ & Short & II-2 \\
\hline 6 & Exiguobacterium sp. TC38-2b & 3 & $+(1.3 \mathrm{~kb})$ & $+(16.8 \mathrm{~kb})$ & $+(16.8 \mathrm{~kb})$ & pKLH3 & $0 \cdot 25-1(5)$ & Long & II-3 \\
\hline 7 & B. cereus $\mathrm{RC} 607$ & 4 & $+(1.3 \mathrm{~kb})$ & $+(6.8 \mathrm{~kb})$ & $+(6.8 \mathrm{~kb})$ & Chromosomes & $0.5->5(7)$ & Long & II-3 \\
\hline 8 & B. cereus VKM684 (ATCC 10702) & 6 & $+(1.3 \mathrm{~kb})$ & $+(6.5 \mathrm{~kb})$ & $+(6.5 \mathrm{~kb})$ & Chromosome & $0 \cdot 5-1(3)$ & Long & II-3 \\
\hline 9 & B. megaterium MK64-1 & 5 & $+(1.3 \mathrm{~kb})$ & $+(4 \cdot 6 \mathrm{~kb})$ & - & pKLH304 & $1-1.5(3)$ & Long & NT \\
\hline 10 & 'B. macroides' TC47-5 & 3 & $+(2 \mathrm{~kb})$ & $+(2$ and $3.8 \mathrm{~kb})$ & - & pKLH305 & $0 \cdot 25-1(3)$ & Long & NT \\
\hline 11 & Unidentified TC22-9 & 3 & $+(3 \mathrm{~kb})$ & $+(3$ and $5 \mathbf{k b})$ & - & Plasmid & $0 \cdot 1-0 \cdot 25(2)$ & Short & II-4 \\
\hline & Unidentified FA11-3 & 1 & \pm & \pm & - & Plasmid & NT & Short & II-7 \\
\hline
\end{tabular}

NT, Not tested.

* Source indicates the area of isolation: 1, the Kamchatka Peninsula ; 2, Central Asia (mouse intestine); 3, Carpathia (Ukraine); 4, Boston Harbor (USA); 5, Kuril Islands; 6, not known (Bogdanova et al., 1992).

†Location of mer operons was determined by Southern hybridization of plasmid DNA preparations with the mer DNA probes as described in Methods. When visible restriction fragments showed hybridization with the probes we concluded that the mer operon was located in a plasmid. In the absence of hybridization of plasmid DNA we considered the mer operon as chromosomal. +, Hybridization of EcoRI fragments(s) with the probes described in Table 2 and shown in Figs 1 and 3(b); -, no hybridization with probe; \pm , weak hybridization with probe.

‡Resistance to PMA was determined as described in Methods. Number of experiments is shown in parentheses. Strains 6-10 show broadspectrum resistance, others show narrow-spectrum resistance. Strain 12 was not tested because it does not grown on LB agar.

\Bogdanova \& Mindlin $(1989,1991)$.

\| Numbering of immunological subtypes from II-1 to II-7 reflects decreasing immunological similarity to MR from B. sphaericus FA8-2. Staphylococcus aureus MR represents the subtype II-7 (Bogdanova et al., 1988).

I Wang et al. (1989).

Table 2. Recombinant plasmids

\begin{tabular}{|c|c|c|}
\hline Plasmid & Phenotype & Description \\
\hline pYW33* & $\mathrm{Hg}^{\mathrm{R}}$ & $12.8 \mathrm{~kb}$ HindIII fragment from RC607 in pUC9 (Fig. 3b) \\
\hline pKLH301.1† & $\mathrm{Hg}^{\mathrm{s}}$ & $9.5 \mathrm{~kb}$ EcoRI fragment from pKLH301 in pACYC184 (Fig. 3a) \\
\hline pKLH302.1† & $\mathrm{Hg}^{\mathrm{s}}$ & $5.5 \mathrm{~kb}$ HindIII fragment from pKLH302 in pACYC184 (Fig. 3a) \\
\hline pKLH302.2 & $\mathrm{Hg}^{\mathrm{s}}$ & $2.8 \mathrm{~kb} \mathrm{BglII}$ fragment from pKLH302.1 in pTZ19 (Fig. 1) \\
\hline pKLH6.1‡ & $\mathrm{Hg}^{\mathrm{R}}$ & $3.2 \mathrm{~kb}$ EcoRI fragment from FA6-12 chromosome in pACYC184 \\
\hline pKLH3.1‡ & $\mathrm{Hg}^{\mathrm{R}}$ & $12.5 \mathrm{~kb}$ HindIII fragment from pKLH3 into pACYC184 (Fig. 3b) \\
\hline pKLH3.2 & $\mathrm{Hg}^{\mathrm{s}}$ & $1.3 \mathrm{~kb}$ EcoRI fragment from pKLH3.1 in pUC19 (Fig. 3b) \\
\hline pKLH3.3 & $\mathrm{Hg}^{\mathrm{s}}$ & $2.1 \mathrm{~kb}$ EcoRI/BglII fragment from pKLH3.1 in pUC19 (Fig. 1) \\
\hline pKLH3.4 & $\mathrm{Hg}^{\mathrm{s}}$ & $1 \cdot 1 \mathrm{~kb} \mathrm{Ncol}$ fragment from pKLH3.1 in pACYC184 (Fig. 3b) \\
\hline pKLH3.5\$ & $\mathrm{Hg}^{\mathrm{s}}$ & $16.8 \mathrm{~kb}$ EcoRI fragment from pKLH3 in pACYC184 \\
\hline pKLH304.1‡ & $\mathrm{Hg}^{\mathrm{R}}$ & $8.0 \mathrm{~kb}$ HindIII fragment from pKLH304 in pACYC184 (Fig. 3b) \\
\hline $\mathrm{pKLH} 304.2 \$$ & $\mathrm{Hg}^{\mathrm{s}}$ & $4.6 \mathrm{~kb}$ EcoRI fragment from pKLH304 in pACYC184 \\
\hline pKLH305.1‡ & $\mathrm{Hg}^{\mathrm{R}}$ & $20 \mathrm{~kb}$ HindIII fragment from pKLH305 in pACYC184 \\
\hline pKLH305.2 & $\mathrm{Hg}^{\mathrm{R}}$ & Self-ligation of $5.8 \mathrm{~kb} \mathrm{NcoI} \mathrm{fragment} \mathrm{from} \mathrm{pKLH305.1}$ \\
\hline
\end{tabular}

* Obtained from I. Mahler, Brandeis University, Waltham, MA, USA.

† Selected by hybridization with the probes pKLH3.2 and pKLH3.3.

¥ Selected by resistance to $10 \mu \mathrm{g} \mathrm{HgCl}_{2} \mathrm{ml}^{-1}$ on LB agar.

SSelected by resistance to $\mathrm{HgCl}_{2}$ in the presence of plasmid pYW22 (obtained from I. Mahler) containing the mercury transport genes (Wang et al., 1987).

were sequenced directly from the PCR fragments. The DNA sequences were compared with those in the Ribosomal Database Project (RDP) (Maidak et al., 1994) and analysed by using the SIMILARITY RANK and ALIGN SEQUENCE programs in RDP, and with those of the NCBI non-redundant database by using the BLAST program (Altschul et al., 1990). To construct 
the dendrograms, sequence alignments were carried out using the vostorg package (Zharkikh et al., 1991). Genetic distances were estimated, bootstrap analysis conducted, and dendrograms constructed by TREECON for Windows version 1.1 (Van de Peer \& De Wachter, 1994).

Mating conditions. Donor (the original TC38-2b, $\mathrm{Hg}^{\mathrm{R}} \mathrm{Rif}^{\mathrm{S}}$ $\mathrm{Str}^{\mathrm{S}}$ ) and recipient (VKM382-2, $\mathrm{Hg}^{\mathrm{S}} \mathrm{Rif}^{\mathbb{R}} \mathrm{Str}^{\mathrm{R}}$ ) cultures were grown separately in LB broth (Sambrook et al., 1989) with the appropriate selection $\left(3 \mu \mathrm{g} \mathrm{HgCl}_{2} \mathrm{ml}^{-1}\right.$ or $10 \mu \mathrm{g}$ rifampicin $\mathrm{ml}^{-1}$ and $20 \mu \mathrm{g}$ streptomycin $\mathrm{ml}^{-1}$, respectively) overnight at $30^{\circ} \mathrm{C}$ with shaking. The cultures were diluted $1: 10$ in fresh LB broth and incubated for a further 6-8 h. After this additional growth, the donor and recipient cultures were mixed in a $1: 1$ ratio; $10 \mu \mathrm{l}$ aliquots of each mixture were spread over a $1 \mathrm{~cm}^{2}$ area on LB agar and incubated for $16-18 \mathrm{~h}$ at $30^{\circ} \mathrm{C}$. The mixed growth was scraped off the plate, resuspended, diluted and plated on selective LB agar to determine the number of c.f.u. of the donor $\left(5 \mu \mathrm{g} \mathrm{HgCl}_{2} \mathrm{ml}^{-1}\right)$, recipient $(30 \mu \mathrm{g}$ rifampicin $\mathrm{ml}^{-1}$ and $100 \mu \mathrm{g}$ streptomycin $\left.\mathrm{ml}^{-1}\right)$, and transconjugants $\left(5 \mu \mathrm{g} \mathrm{HgCl}_{2} \mathrm{ml}^{-1}, 30 \mu \mathrm{g}\right.$ rifampicin ml ${ }^{-1}$ and $100 \mu \mathrm{g}$ streptomycin $\mathrm{ml}^{-1}$ ). The plates were incubated for $24-30 \mathrm{~h}$ at $30^{\circ} \mathrm{C}$. All tested transconjugants which were resistant to both $\mathrm{HgCl}_{2}$ and antibiotics contained a plasmid with the same EcoRI restriction pattern as pKLH3 (data not shown). The pKLH3 transfer frequencies varied from $1.5 \times 10^{-5}$ to $2.5 \times 10^{-6}$ per recipient cell. The frequencies of conversion to $\mathrm{Hg}^{\mathrm{R}}$ in recipient cultures and to antibiotic resistance in donor cultures grown separately on LB agar were less than $1 \times 10^{-8}$.

Determination of narrow- versus broad-spectrum resistance type. Overnight cultures of bacteria grown at $30^{\circ} \mathrm{C}$ in $\mathrm{LB}$ broth containing $1 \mu \mathrm{g} \mathrm{HgCl}_{2} \mathrm{ml}^{-1}$ were supplemented with 4 vols $\mathrm{LB}$ broth containing $0.5 \mu \mathrm{g} \mathrm{HgCl}_{2} \mathrm{ml}^{-1}$. After $1.5 \mathrm{~h}$ incubation bacterial suspensions were diluted to $\mathrm{OD}_{600} 0 \cdot 1$ with $\mathrm{LB}$ broth containing $0.5 \mu \mathrm{g} \mathrm{HgCl}_{2} \mathrm{ml}^{-1} ; 5 \mu$ aliquots were dropped on $\mathrm{LB}$ agar plates containing varying concentrations of $\mathrm{HgCl}_{2}\left(5-80 \mu \mathrm{g} \mathrm{ml}^{-1}\right)$ or PMA $\left(0 \cdot 1-5 \cdot 0 \mu \mathrm{g} \mathrm{ml}^{-1}\right)$, and grown for $24 \mathrm{~h}$ at $30^{\circ} \mathrm{C}$. The highest concentrations of $\mathrm{HgCl}_{2}$ and PMA that did not show inhibition of bacterial growth were recorded.

Plasmid and total DNA preparation. Plasmid DNA from the strains of environmental origin was isolated by alkaline lysis (Birnboim \& Doly, 1979) with modifications. The best yields were obtained when it was possible to grow cells in a poor medium and to lyse them quickly at the lowest possible temperature. Accordingly, strains FA8-2, TC38-2b, MK64-1 and TC47-5 were grown in LB broth; the remaining strains were grown in M9 medium containing aminopeptide and glucose (Bogdanova \& Mindlin, 1991). Both media contained $1 \mu \mathrm{g} \mathrm{HgCl}_{2} \mathrm{ml}^{-1}$. Cell pellets from $10-20 \mathrm{ml}$ overnight cultures were washed with lysis buffer $(50 \mathrm{mM}$ glucose, $25 \mathrm{mM}$ Tris/ $\mathrm{HCl}, \mathrm{pH} 8.0,20 \mathrm{mM}$ EDTA) and incubated in the same buffer containing $2 \mathrm{mg}$ lysozyme $\mathrm{ml}^{-1}$ for $10-20 \mathrm{~min}$ at $37^{\circ} \mathrm{C}$ (strains TA32-5, CH70-2, RC607 and VKM684), for $15 \mathrm{~min}$ at $25^{\circ} \mathrm{C}$ (strain MK64-1), or for 2-30 min at $0-4{ }^{\circ} \mathrm{C}$ (all other strains) with subsequent addition of $\mathrm{NaOH} / \mathrm{SDS}$. Immediately after isolation DNA was deproteinized with phenol/ chloroform according to standard procedures (Sambrook et al., 1989). To isolate total DNA, bacterial lysis was carried out in $10 \mathrm{mM}$ Tris $/ \mathrm{HCl}(\mathrm{pH} 8.0), 50 \mathrm{mM}$ EDTA containing $2 \mathrm{mg}$ lysozyme $\mathrm{ml}^{-1}$ for $1-3 \mathrm{~h}$ at $37^{\circ} \mathrm{C}$ (strains TA32-5, CH70-2, RC607 and VKM684) or for $15-30 \mathrm{~min}$ at $30^{\circ} \mathrm{C}$ (all other strains). The cell suspensions were then rapidly homogenized in EDTA/SDS solution (final concentrations of $0.1 \mathrm{M}$ and $5 \%, \mathrm{w} / \mathrm{v}$, respectively) and mixed with an equal volume of phenol containing $0.1 \%$ hydroxyquinoline, and saturated with $0.1 \mathrm{MEDTA}, 2 \%$ SDS and $0.5 \mathrm{M} \mathrm{NaClO}_{4} \cdot \mathrm{NaClO}_{4}(5 \mathrm{M}$ solution) was added to $0.5 \mathrm{M}$, the mixture was shaken for $30 \mathrm{~min}$ and $0 \cdot 1 \mathrm{vol}$. chloroform was added. After three or four phenol extractions DNA was precipitated by the addition of 1 vol. ethanol, resuspended, and treated with ribonuclease and proteinase according to standard procedures (Sambrook et al., 1989). Recombinant plasmid DNA from $E$. coli was prepared by a standard alkaline lysis procedure (Birnboim \& Doly, 1979). Restriction enzyme digests were carried out by standard procedures (Sambrook et al., 1989). The size of the plasmids was determined as a sum of the molecular masses of their EcoRI fragments.

Southern blot hybridization. DNA probes prepared by restriction enzyme digestion of the recombinant plasmids were excised from low-melting-point $0.7 \%$ agarose Tris/ borate/EDTA (TBE) gels and labelled with $\left[{ }^{32} \mathrm{P}\right] \mathrm{dATP}$ or dCTP by nick-translation (Sambrook et al., 1989). Total and plasmid DNA preparations were digested with the appropriate restriction enzymes and fractionated by electrophoresis on $1 \%$ agarose TBE gels. The DNA was transferred overnight onto BA membrane filters (Schleicher \& Schuell). The filters were prehybridized and then hybridized with the labelled probes for $16 \mathrm{~h}$ at $65^{\circ} \mathrm{C}$ in a solution containing $4 \times \mathrm{SSC}$, $0.1 \%$ SDS, $5 \times$ Denhardt's reagent and $0.1 \mathrm{mg}$ denatured, fragmented calf spleen DNA ml-1. Filters were washed in $10 \mathrm{mM}$ sodium phosphate buffer, $\mathrm{pH} 6.8$, containing $1 \mathrm{mM}$ EDTA and $0.2 \%$ SDS, at room temperature, and exposed to $\mathrm{X}$-ray film at $-70^{\circ} \mathrm{C}$ for $1-7 \mathrm{~d}$.

DNA sequencing. DNA was sequenced by the dideoxy chaintermination method (Sanger et al., 1977) either using an automated DNA sequencer (Applied Biosystems model 370A) with fluorescently labelled dNTP and TaqI polymerase, or manually using ${ }^{33} \mathrm{P}$-labelled dATP and the Sequenase 2.0 DNA sequencing kit (Amersham) in accordance with the manufacturer's instructions. DNA fragments were cloned into plasmids pTZ18 or pTZ19 for sequencing and M13 forward (5' TGAAAACGACGGCCAGT $3^{\prime}$ ) and reverse (5' CAGGAAACAGCTATGAC $3^{\prime}$ ) oligonucleotides (Biotech) were used as sequencing primers. Alignment of DNA sequences was performed using vosTORG (Zharkikh et al., 1991) and BLAST (Altschul et al., 1990) programs.

\section{RESULTS AND DISCUSSION}

\section{Expression and location of mer operons of terrestrial Bacillus strains}

In this work, we studied ten strains from our collection. These included all of the strains containing MRs with long $\mathrm{N}$-terminal domains, and seven strains containing MRs with short $\mathrm{N}$-terminal domains, representing all immunological subtypes (Table 1). We failed to detect statistically significant differences in $\mathrm{HgCl}_{2}$ resistance levels within the collection studied, although in vitro testing may not be sufficiently sensitive to detect differences that are only evident under environmental conditions. However, the strains containing MRs with short N-terminal domains were PMA sensitive, whilst those containing MRs with long $\mathrm{N}$-terminal domains were PMA resistant, i.e. displayed broad-spectrum resistance. Only one of the broad-spectrum resistant strains contained a merB gene detectable by hybridization with the merB gene of the RC607 mer (Table 1). This indicates that different merB genes exist in Bacillus 
strains, as was recently shown for the merB genes of Gram-negative bacteria (Reniero et al., 1995).

Nine strains contained mer operons that effectively hybridized with DNA probes to merR, the transport genes, or the merA gene of the TC38-2b mer operon (Table 1). One strain (FA11-3) carried a mer operon that showed weak hybridization with these probes. All strains listed in Table 1 except TA32-12 were found to contain plasmids. DNA hybridization experiments demonstrated that the mer operons resided on plasmids in most of the strains (Table 1). For TC38-2b, TC47-5 and FA8-2, this conclusion was confirmed in Southern hybridization experiments with $\mathrm{Hg}^{\mathrm{s}}$ derivatives of these strains (Bogdanova \& Mindlin, 1991) that had lost $\mathrm{HgCl}_{2}$ resistance as a result of plasmid elimination. Plasmid preparations from these $\mathrm{Hg}^{\mathrm{S}}$ derivatives did not hybridize with the mer probes.

A mercury-resistance plasmid, pKLH3, found in Exiguobacterium sp. TC38-2b, was transferred by conjugation from $\mathrm{TC} 38-2 \mathrm{~b}$ to its plasmidless $\mathrm{Hg}^{\mathrm{S}}$ derivative. This suggests that pKLH3 and other plasmids listed in Table 1 could be involved in the horizontal transfer of mer operons. Surprisingly, no plasmids were found in the Minamata Bay collection (Nakamura \& Silver, 1994). It is unclear whether this is due to possible technical problems of plasmid isolation from certain Bacillus strains or reflects a real local variation characteristic of a particular habitat.

Three mer operons encoding MRs with the long Nterminal domains (from Exiguobacterium sp. TC38-2b, Bacillus megaterium MK64-1 and 'B. macroides' TC475 ) and three mer operons encoding MRs with the short $\mathrm{N}$-terminal domain, representing the most common immunological subtypes (from B. sphaericus FA8-2, $B$. cereus TA32-5 and B. licheniformis FA6-12), were cloned as described in Methods. In E. coli, the cloned mer operons from TC38-2b and FA6-12 expressed MR activity constitutively, while the TC47-5 operon showed $\mathrm{HgCl}_{2}$-inducible MR activity (data not shown); all three mer operons conferred mercury resistance to $E$. coli. The mer operons from strains FA8-2 and TA32-5 did not express mercury resistance and MR activity in E. coli, but all of the mer operons studied showed inducible $M R$ activity in their original host strains (data not shown). The cause of the differences in the expression of the mer operons is under investigation.

\section{Restriction mapping suggests a high diversity of mer operons of terrestrial Bacillus strains, and long-distance geographical spread of at least two mer operon variants}

Five distinct variants were identified among the cloned mer operons, by Southern blot mapping with 12 restriction endonucleases (Fig. 1). The mer operon variant found in $\mathrm{TC} 38-2 \mathrm{~b}$ was indistinguishable from the mer operon of RC607. Identical mer operons were found in TA32-5 and FA8-2. Plasmid DNA Southern blot mapping using seven restriction endonucleases revealed no differences between the $\mathrm{CH} 70-2$, TA32-5 and FA8-2 mer operons and between the VKM684, TC38-2b and RC607 (Fig. 1). The mer operons from FA6-12, MK64-1 and TC47-5 were different from each other and from the TC38-2b/RC607/VKM684 and TA32-5/FA8-2/CH70-2 operons. We failed to construct a definitive mer operon map for strain TA32-12, since this apparently contained two mer operons. A rudimentary map of TC22-9 suggested that it contained a unique variant mer operon distinct from those shown in Fig. 1. The mer operon from FA11-3 showed poor hybridization with the R607 mer and obviously represented a separate variant. Thus, at least seven distinct variants of mer operons can be recognized at the DNA sequence level among the ten strains studied. The DNA sequence classification of mer operon variants was in agreement with the immunological typing of MRs (Table 1). It remains to be elucidated whether the observed diversity of the mer $A$ and mer $B$ gene structures and variations in the regulation of mer operon expression detected in this paper reflect environmental selection.

Formally, the same number of restriction map classes of mer operons was recognized in the Minamata Bay collection and in our collection. On closer inspection, the mer operons of the Minamata Bay collection are actually less diverse than the mer operons from our collection. Indeed, the differences within classes I-IV and V-VI identified by Nakamura \& Silver (1994) are minor ones and mainly depend on the presence or absence of a single $B g$ III site. This may not be a real difference, but may be a reflection of the protection of BglII sites, possibly by methylation, in certain Bacillus strains, as was noted in our work for strains FA8-2 and TA32-12 (see Fig. 1 legend).

Comparison of our collection with the Minamata Bay collection suggests that local populations may differ considerably in the prevalence of various mer operon variants. Thus, the narrow-spectrum mer operons encoding MRs with a single $\mathrm{N}$-terminal domain are major variants in our collection, but are absent or very rare in the Minamata Bay population. The broad-spectrum mer operons of the RC607 type, encoding MRs with a duplicated N-terminal domain, flourish in Minamata Bay sediments (Nakamura \& Silver, 1994), but seem to be minor components of the terrestrial $\mathrm{Hg}^{\mathrm{R}}$ Bacillus populations so far analysed (Bogdanova \& Mindlin, 1989,1991 ; this paper). It would be interesting to learn whether this is a peculiarity or a general property of marine sediment populations.

Only one mer operon variant was common to both our terrestrial strain collection and the Minamata Bay marine sediment collection. This variant, whose presence is reported in strain VKM684 (this paper) was isolated from a non-documented locale and habitat (Dornbush \& Pelcak, 1948), in strains from the USA (Wang et al., 1989), Japan (Nakamura \& Silver, 1994), Ukraine (this paper) and Great Britain (Osborn et al., 1997), and is apparently distributed worldwide. We hypothesize that the mer variant found in TA32-5, FA8-2 and $\mathrm{CH} 70-2$ is also disseminated all over the 


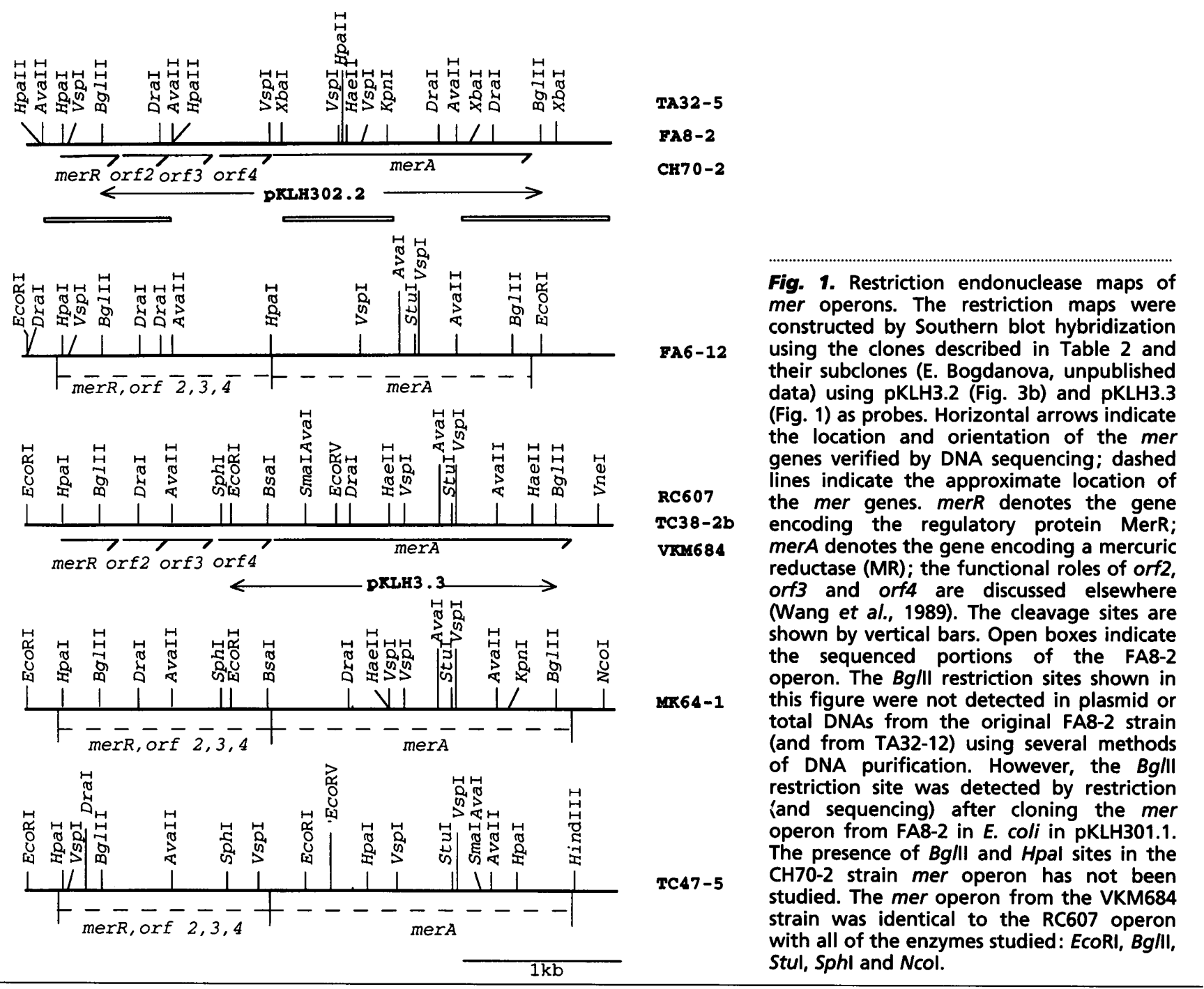

world since we were able to detect it in two geographically separated terrestrial habitats (Kamchatka and Central Asia) in a survey of only ten strains. Further studies are required to outline the geographical distribution of other mer operon variants described in this work.

\section{mer operons representing the same restriction map variant show no DNA sequence divergence, while different variants show $20 \%$ DNA sequence divergence}

We have determined the complete nucleotide sequence of two mer operon variants. Sequence analysis confirmed that these mer operons had the same relative gene organization as that of the RC607 mer. Inspection of the sequences at the beginning of the mer $A$ genes confirmed our earlier suggestion, based on limited proteolysis data, that the MR of TC38-2b had a duplicated N-terminal domain, while TA32-5 had a single such domain. The mer operon of Exiguobacterium sp. TC38-2b (from Carpathia, Ukraine) was virtually identical to that of
Bacillus cereus RC607 from Boston Harbor, USA (nine nucleotide substitutions over $4 \cdot 2 \mathrm{~kb}$ of sequenced DNA, i.e. $0 \cdot 2 \%$ difference), while that of TA32-5 showed a $20 \%$ difference from RC607. We determined the DNA sequence of $1.8 \mathrm{~kb}$ of the mer operon of FA8-2 (Fig. 1) and found that it was identical to the sequence of the mer operon of TA32-5.

\section{$16 S$ rRNA sequence characterization of mercury- resistant strains suggests horizontal transfer of two mer operon variants}

Finding virtually identical mer operons in bacteria isolated from different parts of the world may indicate either wide dissemination of a particular strain - a high rate of strain migration in natural populations of certain Bacillus species has been demonstrated by Roberts \& Cohan (1995) - or wide horizontal dissemination of the mer operon between distinct strains. To resolve this question we sequenced the 16S rRNA genes of the strains carrying the mer operons shown in Fig. 1. The 16S rRNA gene region 343-709 sequence of strain TC38- 
(a)

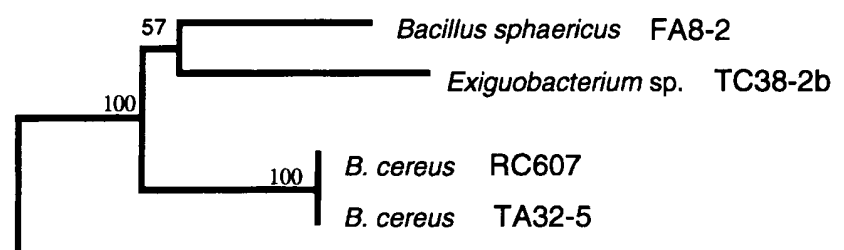

Staphylococcus aureus

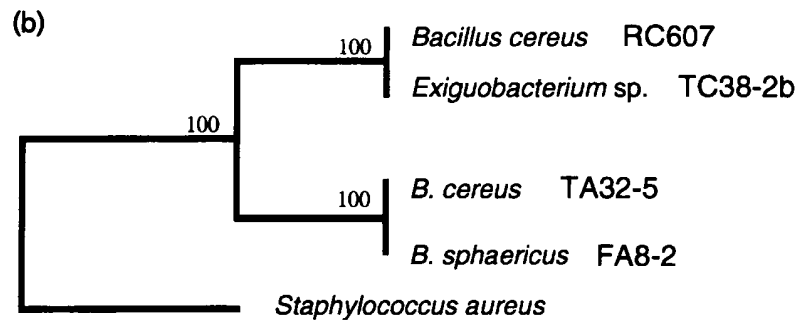

0.05

Fig. 2. Neighbour-joining distance dendrograms of the $16 \mathrm{~S}$ rRNA gene fragment 343-709, showing the relationship between the strains from our collection (a) and the merA gene from the same strains (b). The accession numbers for the merA genes are: $B$. cereus RC607, M22708; Exiguobacterium sp. TC382b, X99457; B. cereus TA32-5, Y09024; B. sphaericus FA8-2, Y10104 and Y10105. Staphylococcus aureus was used as the formal outgroup strain. The 16S rRNA and merA (pl258) accession numbers are D83353 and L29436, respectively. Genetic distance was estimated by the Jukes-Cantor algorithm. The distance scale indicates the number of nucleotide substitutions per site that have actually occurred since divergence of each pair of sequences. The distance between any two sequences is the sum of the lengths of the horizontal branches between the two; (a) and (b) are drawn to different scales, as indicated. Bootstrap percentages (100 replicates) are shown to the left of the node being considered. EMBL accession numbers for $16 \mathrm{~S}$ RNA sequences nt 343-709 are: Exiguobacterium TC38-2b, Y15051; Bacillus cereus RC607, Y15048; B. cereus TA32-5, Y15050; and B. sphaericus FA8-2, Y15045.

$2 \mathrm{~b}$ showed $99.7 \%$ identity with that of Exiguobacterium sp. (GenBank accession number X86064) and 98.5\% identity with that of E. acetylicum (GenBank accession number D55730). These identification data were in agreement with the fatty acid analysis of strain TC38-2b that was kindly conducted by Dr K. J. Purdy (Natural Environment Research Council Institute of Virology and Environment Microbiology, Oxford, UK). The nucleotide sequences of the 343-709 16S rRNA gene region from strains RC607, TA32-5 and VKM684 were identical to that of a reference $B$. cereus strain (GenBank accession number D16266), while the nucleotide sequence of the corresponding fragment from strain CH70-2 showed $99.7 \%$ identity with that of the reference $B$. cereus strain. This difference may be an

artifact of selecting one of the multiple $r r n$ sequences which are present in B. cereus (Johansen et al. 1996). So, strains R C607, TA32-5, VKM684 and CH70-2 fell into a group of very closely related species, which include $B$. cereus, B. thuringiensis, B. anthracis and B. mycoides (Ash et al., 1991). Data on bacterial cell mobility, haemolysis, and colony morphology suggested that all four strains were $B$. cereus. Strains RC607, TA32-5 and $\mathrm{CH} 70-2$ were not identical, since they differed in their products of repetitive extragenic palindromic sequence PCR (de Bruijn, 1992). Strain FA8-2 was identified as $B$. sphaericus $(99.1 \%$ identity with the $16 \mathrm{~S}$ rRNA gene fragment of a reference B. sphaericus strain; GenBank accession number D16280). The $16 \mathrm{~S}$ rRNA of RC607, and that of TC38-2b differed at $10 \%$ of nucleotide positions. Using a calibration of the molecular clock for 16S rRNA (Ochman \& Wilson, 1987) we estimate that these strains diverged approximately 500 million years ago. The small difference between the sequences of the mer operons found in strains RC607 and TC38-2b $(<0.2 \%)$ suggests that the time elapsed after their divergence is much smaller than that for $16 \mathrm{~S}$ rRNA. Accordingly, we conclude that one or both of these strains, and possibly VKM684, acquired their mer operons relatively recently due to horizontal transfer (Fig. 2). This conclusion is graphically confirmed by the comparison of phylogenetic trees for the $16 \mathrm{~S}$ and merA genes. Fig. 2(a, b) shows that the phylogenies of the $16 \mathrm{~S}$ rRNA and merA genes are not congruent. Horizontal mer operon transfer is also evident for strains FA8-2 and TA32-5, which show $9 \%$ nucleotide differences between the 16S RNA genes, and no difference in their mer operons (Fig. 2a, b). TA32-5 and CH70-2 show 0-3\% difference between their $16 \mathrm{~S}$ rRNA sequences, so we can not exclude vertical inheritance of the mer operons between these strains. The source of mer operons in the transfer studied is unknown: the $\mathrm{G}+\mathrm{C}$ content of mer operons of RC607 and TC38-2b (39 mol\%); TA32-5 and FA8-2 $(40 \mathrm{~mol} \%)$ is in the range of the chromosome $\mathrm{G}+\mathrm{C}$ content for the Bacillus strains: RC607 (33 $\mathrm{mol} \%)$, TC38-2b (44 mol \%), TA32-5 (30 $\mathrm{mol} \%)$ and FA8-2 (35 mol\%). In the Minamata Bay collection, the RC607 mer operon variant was found in strains phenotypically identified as B. subtilis, B. firmus, $B$. lentus and B. badius. It is possible that the RC607 mer operon variant experienced horizontal transfer amongst these species. However, definitive testing of this hypothesis requires sequencing of the mer operons and $16 \mathrm{~S}$ RNA genes of these organisms, and the construction and comparison of evolutionary trees based on these data.

\section{DNA sequencing downstream of mer operons suggests involvement of class II transposons in dissemination of mercury resistance in Gram-positive bacteria}

In looking for the possible involvement of transposons in translocations of mer operons from plasmids to chromosome and between plasmids, we characterized the regions flanking the mer operons. Southern hybridization restriction mapping and partial DNA sequencing 
(a)

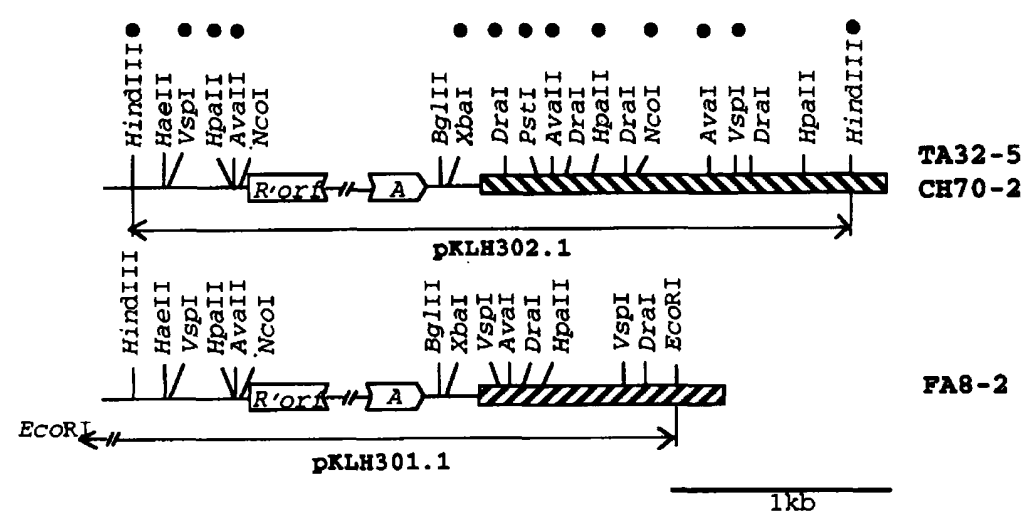

(b)

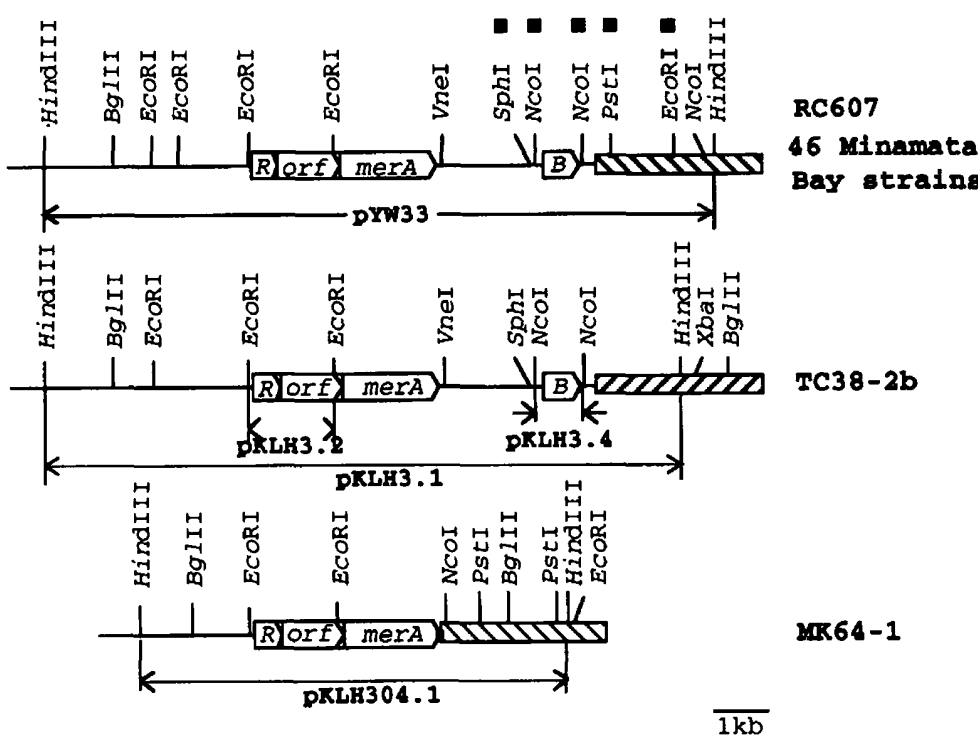

\begin{abstract}
Fig. 3. Restriction endonuclease maps of regions flanking mer operons; (a) and (b) are drawn to different scales, as indicated. For TA32-5, FA8-2, RC607, TC38-2b and MK64-1 strains, the restriction maps were constructed by Southern hybridization of cloned fragments described in Table 2 with pKLH3.2, pKLH3.3, pKLH3.4 and pKLH302.2 as probes. $R$, orf and $A$ denote the merR, orf2-orf3-orf4 and merA genes, respectively. For $\mathrm{CH} 70-2$, the plasmid DNA was probed with PKLH302.2 using the restriction enzymes marked by filled circles. Filled squares mark restriction sites also present in the Minamata Bay strains (Nakamura \& Silver, 1994). The boxes downstream of the mer operons represent DNA fragments following the transposon IRs. The sequences surrounding these IRs are shown in Fig. $4(a, b)$.
\end{abstract}

demonstrated that the high degree of similarity between TA32-5 and FA8-2 on the upstream side of the mer operons, continued up to the leftmost $H$ indIII site shown in Fig. 3(a). The exact position where homology was lost was not determined. The identity of the TC32-5 and FA8-2 DNA sequences downstream of $m e r A$ continued for $220 \mathrm{bp}$ to the end of an element (109 bp) showing $85 \%$ identity with the transposase-distal end of a class II (Tn3 family) vancomycin-resistance transposon Tn1546 from a clinical Enterococcus strain (Fig. 4a). For TA325 and $\mathrm{CH} 70-2$, restriction mapping demonstrated that high similarity or identity continued much further beyond the end of the putative transposon (Fig. 3a). This suggests that the transposons found in these strains are located in related plasmids.

Southern hybridization restriction mapping demonstrated that the high degree of similarity between RC607 and TC38-2b on the upstream side of the mer operons continued beyond the leftmost HindIII site shown in Fig. 3 (b). The exact position where the homology finished was not determined. On the downstream side, both strains contained identical mer $B$ genes separated from the end of $m e r A$ by a $1.8 \mathrm{~kb}$ region with an undefined function (Fig. 3b). This region was not compared by DNA sequencing but was probably identical in the two strains. The identity continued for $635 \mathrm{bp}$ downstream of the mer $B$ gene and finished precisely at the end of a $38 \mathrm{bp}$ element showing up to $60 \%$ identity with IRs of class II transposons (Fig. 4b). This element was preceded by a $162 \mathrm{bp}$ region encoding a peptide showing homology with the C-terminal end of class II transposases (Fig. 5). Sequence analysis demonstrated that the putative transposon found in strains RC607 and TC38-2b was more distantly related to $\mathrm{Tn} 1546$ than the putative transposon found in TA32-5 (Fig. 4b and Fig. 4a). However, the putative transposon found in RC607 and TC $38-2 b$ was slightly more closely related to a Tn1546-Tn5044 branch of class II transposons (Yurieva \& Nikiforov, 1996; Kholodii et al., 1997), containing transposons from Gram-positive bacteria, than to the Tn21 branch containing transposons from Gram-negative bacteria. Southern hybridization restriction mapping demonstrated the absence of homology between downstream mer operon regions from RC607 and VKM684.

From mapping data for RC607 and numerous Minamata 
(a)

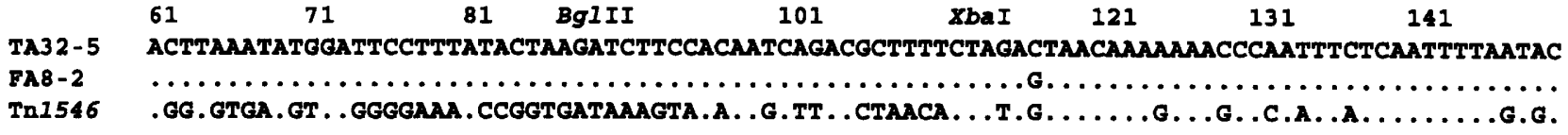

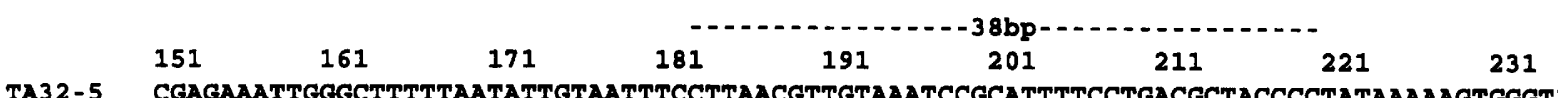

\section{FA8 - 2}

$\operatorname{Tn} 1546$

TA32 -5
FA $8-2$
Tn 154

(b)

\section{RC607}

TC3 $8-2 b$

RC607

TC3 $8-2 b$

\section{1 \\ 261 \\ 271 \\ 281 \\ 291 \\ ATATTTTCTTATTCCCCTTITCGGGgGATGGOCAAAAACACCCCTTTGCTATCGAT}

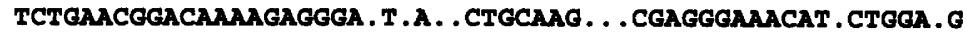

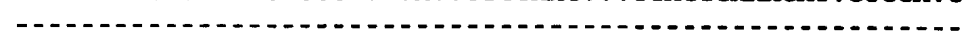

35

361

371 G I $\quad$ K

391

401

411

421

$\begin{array}{lllllllllllllllll}R & R & I & G & Q & I & C & T & N & I & S & I & R & E & D & L\end{array}$

TGCGGATGTTCCCTCGTACGACTAGgGATTGAAAAAGATAGGGCAGCTGTGTACAAATATAAGTTTACGAGAAGACCTGC

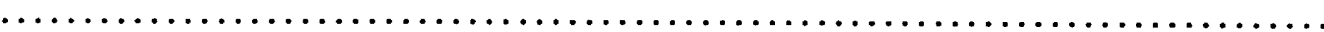

$\begin{array}{lllllllll}431 & 441 & 451 & 461 & 471 & 481 & 491 & 501\end{array}$

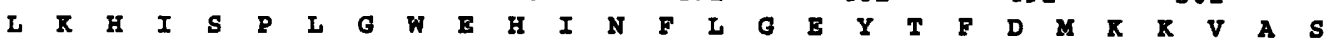

TAAAACATATTTCTCATTGGGATGGGAACATATTAATTTCTTGGCGAATACACATTTGATATGAAGAAAGTAGCAAGT

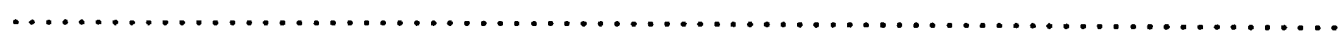

$\begin{array}{llrrrrrr}511 & 521 & 531 & 541 & 551 & 561 & 571 & 581\end{array}$

RC607

TC38-2b

MK64-1

$\operatorname{Tn} 1546$

\section{TTATATTCACTACGCCCTCTTATTCAATAATACTAAAGGCCGATGATTCCTTAGGTAGGGAAAATCGCTTTTTTCCTCA}

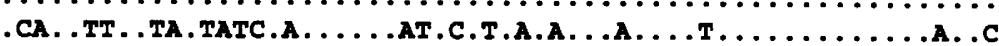

C.C.AT.GT.ACAA.G.AAg. CCAAT.AT.AATTT. . T. CTG.GGAT.GG.C. . T. T.

RC607

TC3 8-2b

MR64-1

Tn1546

TA32-5

$\operatorname{Tn} 4430$

Tn21

$\operatorname{Tn} 3$

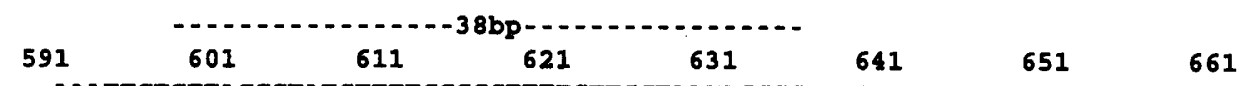

\section{- AAATCTCTTAGCGTATGTTTтCCGCGTTTTGTTGgTAATACCCCTTAGAGAGGTTAGAAAAACGTTTATTTGACGA}

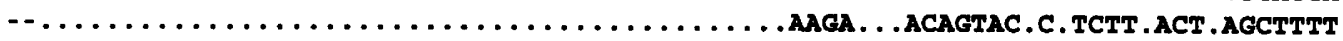

AG....G....A......A.T.........GG....A.A....GATTTTCTAACAAG.ACA. TG

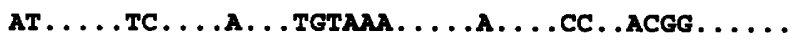

..... . TGTAAA. . . . . . . CC. . ACGC.....

....... GGT. . . TTC. .AAA. . . . . CGG. . . . .

-...... GCT. . A.TTT.CG. . TC. .AG.CG....

......GA.....GTTCCAC..AGC..C.G....

Fig. 4. (a) Alignment of the regions downstream of merA from Bacillus cereus TA32-5 and B. sphaericus FA8-2 strains, with the Enterococcus faecium transposon Tn1546 transposase-distal end. The numbering is from the first nucleotide after the merA gene. A dot indicates a base identical to that in the $B$. cereus TA32-5 sequence; a gap is indicated by a dash. The 38 bp transposon IR is overlined. The EMBL database accession numbers for these sequences are: TA32-5, Y09024; FA82, Y10105; Tn1546, M97297. (b) Alignment of the regions downstream of the merB gene from the $B$. cereus RC607 chromosome and an Exiguobacterium sp. TC38-2b plasmid (pKLH3) with the region downstream of the merA gene from B. megaterium MK64-1 plasmid (pKLH304). The terminal IRs of the putative transposons from RC607/TC38-2b, MK64-1, and TA32-5/FA8-2 are aligned with IRs of class II transposons. Numbering is from the first nucleotide after the merB gene, except in the MK64-1 sequence where it is from that after the merA gene. A dot indicates a base identical to that of the $B$. cereus sequence. No differences were detected in the DNA sequence of the first 635 bp after the end of merB gene, between the RC607 chromosome and Exiguobacterium sp. TC38-2b plasmid, pKLH3. In our hands, the sequence of RC607 chromosome differed from the published data (Wang et al., 1989) by twelve single-base extensions of homonucleotide tracks in the $100 \mathrm{bp}$ following the merB gene. The amino acid sequence of the putative transposase fragment of the RC607/TC38-2b transposon is shown above the nucleotide sequence. The sequences of IRs of Tn1546 from Enterococcus faecium, Tn4430 from B. thuringiensis, Tn21 from Shigella flexneri and Tn3 from E. coli are from Arthur et al. (1993). The accession numbers for other sequences are: RC607, Y08065; pKLH3, Y08064; pKLH304, Y09907; pKLH302, Y09024. 


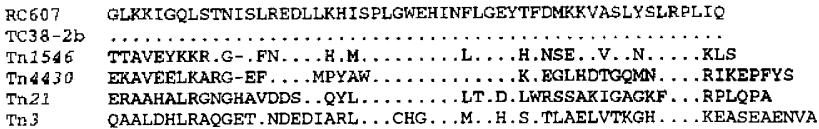

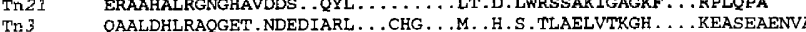

Fig. 5. Sequence similarity between the deduced amino acid sequences of the transposase fragment of the putative transposon of $\mathrm{RC} 607 / \mathrm{TC} 38-2 \mathrm{~b}$ strains and of the class II transposases. The alignment of transposases at their $\mathrm{COOH}$ end is from Yurieva \& Nikiforov (1996).

Bay strains (Nakamura \& Silver, 1994), we conclude that the high similarity or identity between these strains continues further beyond the end of the putative transposon (Fig. 3b). This suggests that the suspected horizontal transfer of mer operons between the replicons of these strains (see the section above on 16S rRNA sequence) involved a larger element than the transposon found in the RC607 strain. It would be interesting to explore the nature of this element by examining the extent of similarity between different Minamata Bay strains on both sides of the mer operons.

Inspection of the sequence downstream of the merA gene of MK64-1 demonstrated that it bore no homology to the sequence downstream of the merA gene of RC607, but showed high similarity to the transposon element found downstream of the merB gene in RC607 and TC38-2b (Fig. 4b). This suggests that MK64-1 contains a transposon (closely related to the transposon from RC607) from which a merB gene-containing fragment may have been deleted. This may explain why the MK64-1 DNA did not hybridize with the merB gene of RC607 (Table 1).

The identification of at least three different class II transposon sequences adjacent to the mer operons described above, suggests that this family of transposons was involved in dissemination of mercury resistance not only in Gram-negative bacteria but also in Grampositive bacteria. It remains to be elucidated whether the putative transposons reported in this paper contain a complete set of transposition genes or are defective, as has often been found in Gram-negative bacteria (Yurieva et al., 1997).

\section{Conclusions and perspectives}

The principal result of this study is that a geographical and horizontal dissemination of mer operons in low $\mathrm{G}+\mathrm{C}$ content Gram-positive bacteria in the natural environment has occurred, mirroring the worldwide dissemination of mer operons in Gram-negative bacteria (Osborn et al., 1997; Yurieva et al., 1997). Class II (Tn3like) transposons were apparently involved in this process. As in the case of Gram-negative bacteria (Yurieva et al., 1997), the spread of mer operons reported in this paper was detected in a survey of a very small collection of strains. This suggests that promiscuous clones of mer operons constitute a considerable, if not the major, fraction of the worldwide population of $\mathrm{mer}$ operons in culturable environmental isolates of bacteria. This conclusion does not eliminate the existence of strictly local clones of mer operons, but suggests that detection of these would require the large-scale screening of culture collections from all over the world.

The timing and the driving force of the spread of the mer operons remains an open question. One possibility is that the observed dissemination occurred because of increased selective pressure caused by recent industrial pollution. Another possibility is that the spread of mer operons occurs periodically and occurs over longer time spans, as has been postulated for the periodic replacement of chromosomal alleles in E. coli populations (Milkman \& McKane, 1995). That would mean that the worldwide distributions that we detect now are neither the first nor the last pandemics in the history of mer operons. A promising way to investigate this issue further is to compare mer operons from palaeobacteria, which have been preserved in permafrost grounds for more than 30000 years (Gilichinsky et al., 1992), with presentday bacteria, and to compare the mer gene distribution amongst Gram-positive bacteria isolated from sites with different levels of mercury contamination.

\section{ACKNOWLEDGEMENTS}

This research was supported by the Russian Foundation for Basic Research, grant 95-04-11923-a (to E.B.), National Institutes of Health FIRCA grant TW00396-02 (to R.N. and V.N.), NSF grant INT-9315089 (to J.T.), and grants from the MRC (G.9309093) and BBSRC (C/04148) to N.L.B. We thank Dr R. Novick for support, two anonymous referees for comments and helpful suggestions, Dr I. Mahler for the Bacillus sp. RC607 strain, mer-operon-containing plasmids, helpful comments, and good advice; Dr K. J. Purdy for the identification of TC38-2b strain by fatty acid analysis; E. I. Molchanova for technical assistance and S. Yu. Nechaev for help in preparing the manuscript.

\section{REFERENCES}

Altschul, S. F., Gish, W., Miller, W., Myers, E. W. \& Lipman, D. J. (1990). Basic local alignment search tool. J Mol Biol 215, 403-410.

Arthur, M., Molinas, C., Depardieu, T. \& Courvalin, P. (1993). Characterization of $\operatorname{Tn} 1546$, a $\operatorname{Tn} 3$-related transposon conferring glycopeptide resistance by synthesis of depsipeptide peptidoglycan precursors in Enterococcus faecium BM 4147. J Bacteriol $175,117-127$.

Ash, C., Farrow, J. A. E., Dorsch, M., Stackebrandt, E. \& Collins, M. D. (1991). Comparative analysis of Bacillus antbracis, Bacillus cereus, and related species on the basis of reverse transcriptase sequencing of $16 \mathrm{~S}$ rRNA. Int J Syst Bacteriol 41, 343-346.

Begley, T.P., Walts, A. E. \& Walsh, C. T. (1986). Mechanistic studies of a protonolytic organomercurial cleaving enzyme: bacterial organomercurial lyase. Biochemistry 25, 7192-7200.

Belliveau, B. H. \& Trevors, J. T. (1990). Mercury resistance determined by a self-transmissible plasmid in Bacillus cereus 5 . Bio Metals 3, 188-196.

Birnboim, H. C. \& Doly, J. (1979). A rapid alkaline extraction procedure for screening recombinant plasmid DNA. Nucleic Acids Res 7, 1513-1523. 
Bogdanova, E. S. \& Mindlin, S. Z. (1989). Two structural types of mercury reductases and possible ways of their evolution. FEBS Lett 247, 333-336.

Bogdanova, E. S. \& Mindlin, S.Z. (1991). Occurrence of two structural types of mercury reductases among Gram-positive bacteria. FEMS Microbiol Lett 78, 277-280.

Bogdanova, E. S., Mindlin, S. Z., Kalyaeva, E. S. \& Nikiforov, V. G. (1988). The diversity of mercury reductases among mercuryresistant bacteria. FEBS Lett 234, 280-282.

Bogdanova, E. S., Mindlin, S. Z., Pakrova, E., Kocur, M. \& Rouch, D. A. (1992). Mercuric reductase in environmental Gram-positive bacteria sensitive to mercury. FEMS Microbiol Lett 97, 95-100.

Brown, N. L., Lund, P. L. \& Ni'Bhrian, N. (1989). Mercury resistance in bacteria. In The Genetics of Bacterial Diversity, pp. 175-195. Edited by D. A. Hopwood \& K. F. Chater. London \& New York: Academic Press.

de Bruijn, F. J. (1992). Use of repetitive (repetitive extragenic palindromic and enterobacterial repetitive intergeneric consensus) sequences and the polymerase chain reaction to fingerprint the genomes of Rhizobium meliloti isolates and other soil bacteria. Appl Environ Microbiol 58, 2180-2187.

Cano, R. J., Borucki, M. K., Higby-Schweitzer, M., Poinar, H. N., Poinar, G. O., Jr \& Pollard, K. J. (1994). Bacillus DNA in fossil bees: an ancient symbiosis? Appl Environ Microbiol 60, 2164-2167.

Claus, D. \& Berkely, R. C. W. (1986). Genus Bacillus Cohn 1872 174 AL. In Bergey's Manual of Systematic Bacteriology, vol. 2, pp. 1105-1139. Edited by P. H. A. Sneath, N. C. Mair, M. E. Sharpe \& J. G. Holt. Baltimore: Williams \& Wilkins.

Dornbush, A. C. \& Pelcak, E. J. (1948). Assay of aureomycin level in body fluid. Ann NY Acad Sci 51, 218-220.

Gadd, G. M. (1990). Metal tolerance. In Microbiology of Extreme Environments, pp. 179-210. Edited by C. Edwards. Milton Keynes: Open University Press.

Gilbert, M. P. \& Summers, A. O. (1988). The distribution and divergence of DNA sequences related to Tn21 and Tn501 mer operons. Plasmid 20, 127-136.

Gilichinsky, D. A., Vorobyova, E. A., Erochina, L. G., FyodorovDavydov, D. G. \& Chaikovskaya, N. R. (1992). Long-term preservation of microbial ecosystems in permafrost. Adv Space Res $12,(4) 255-(4) 263$

Grinsted, J., De La Cruz, F. \& Schmitt, R. (1990). The Tn21 subgroup of bacterial transposable elements. Plasmid 24, 163-189.

Hobman, J. L. \& Brown, N. L. (1997). Bacterial mercury resistance genes. In Metal Ions in Biological Systems, vol. 34, pp. 527-567. Edited by H. Sigel \& A. Sigel. New York: Marcel Dekker.

Hobman, J. L., Kholodii, G. Ya., Nikiforov, V. G., Ritchie, D. A., Strike, P. \& Yurieva, O. V. (1994). The sequence of the mer operon of $\mathrm{p} M E R 327 / 419$ and transposon ends of pMER.327/419, 330 and 05 . Gene 146, 73-78.

Johansen, T., Carlson, C. R. \& Kolsto, A.-B. (1996). Variable numbers of rRNA gene operons in Bacillus cereus strains. FEMS Microbiol Lett 136, 325-328.

Kholodii, G. Ya., Gorlenko, Zh. M., Lomovskaya, O. L., Mindlin, S. Z., Yurieva, O. V. \& Nikiforov, V. G. (1993a). Molecular characterization of an aberrant mercury resistance transposable element from an environmental Acinetobacter strain. Plasmid 30, 303-308.

Kholodii, G. Ya., Yurieva, O. V., Lomovskaya, O. L., Gorlenko, Zh. M., Mindlin, S. Z. \& Nikiforov, V. G. (1993b). Tn5053, a mercury resistance transposon with integron's ends. $J \mathrm{Mol} \mathrm{Biol}$ 230, 1103-1107.
Kholodii, G. Ya., Mindlin, S. Z., Bass, I. A., Yurieva, O. V., Minakhina, S. V. \& Nikiforov, V. G. (1995). Four genes, two ends, and a res region are involved in transposition of $\operatorname{Tn} 5053$ : a paradigm for a novel family of transposons carrying either a mer operon or an integron. Mol Microbiol 6, 1189-1200.

Kholodii, G. Ya., Yurieva, O. V., Gorlenko, Zh. M., Mindlin, S. Z., Bass, I. A., Lomovskaya, O. L., Kopteva, A. V. \& Nikiforov, V. G. (1997). Tn5041: a chimeric mercury resistance transposon closely related to the toluene degradative transposon Tn4651. Microbiology 143, 2549-2556.

Laddaga, R. A., Chu, L., Misra, T. K. \& Silver, S. (1987). Nucleotide sequence and expression of the mercurial resistance operon from Staphylococcus aureus plasmid p1258. Proc Natl Acad Sci USA 84, 5106-5110.

Liebert, C. A., Wireman, J., Smith, T. \& Summers, A. O. (1997). Phylogeny of mercury resistance (mer) operons of Gram-negative bacteria isolated from the fecal flora of primates. Appl Environ Microbiol 63, 1066-1076.

Mahler, I., Levinson, H. S., Wang, Y. \& Halvorson, H. O. (1986). Cadmium- and mercury-resistant Bacillus strains from a salt marsh and from Boston Harbor. Appl Environ Microbiol 52, 1293-1298.

Maidak, B. L., Larsen, N., McGaughey, M. J, Overbek, R. , Olson, G. J., Fogell, K., Blandy, J. \& Woese, C. R. (1994). The Ribosomal Database Project. Nucleic Acids Res 22, 3485-3487.

Milkman, R. \& McKane, M. (1995). DNA sequence variation and recombination in E. coli. In The Population Genetics of Bacteria (Society for General Microbiology Symposium vol. 52), pp. 127-142. Edited by S. Baumberg, J. P. W. Young, E. M. H. Wellington \& J. R. Saunders. Cambridge: Cambridge University Press.

Misra, T. K. (1992). Bacterial resistances to inorganic mercury salts and organomercurials. Plasmid 25, 4-16.

Nakahara, H., Ishikawa, T., Sarai, Y., Kondo, I. \& Mitsuhashi, S. (1977). Frequency of heavy-metal resistance in bacteria from inpatients in Japan. Nature 266, 165-167.

Nakamura, K. \& Silver, S. (1994). Molecular analysis of mercuryresistant Bacillus isolates from sediment of Minamata Bay, Japan. Appl Environ Microbiol 60, 4596-4599.

Ochman, H. \& Wilson, A. C. (1987). Evolution in bacteria : evidence for a universal substitution rate in cellular genomes. J Mol Evol 26, 74-84.

Olson, B. H., Lester, J. N., Cayless, S. M. \& Ford, S. (1989). Distribution of mercury resistance determinants in bacterial communities of river sediments. Wat Res 23, 1209-1217.

Osborn, A. M., Bruce, K. D., Strike, P. \& Ritchie, D. A. (1995). Sequence conservation between regulatory mercury resistance genes in bacteria from mercury polluted and pristine environments. Syst Appl Microbiol 18, 1-6.

Osborn, A. M., Bruce, K. D., Ritchie, D. A. \& Strike, P. (1996). The mercury resistance operon of the IncJ plasmid pMERPH exhibits structural and regulatory divergence from other Gram-negative mer operons. Microbiology 142, 337-345.

Osborn, A. M., Bruce, K. D., Strike, P. \& Ritchie, D. A. (1997). Distribution, diversity and evolution of the bacterial mercury resistance (mer) operon. FEMS Microbiol Rev 19, 239-262.

Reniero, D., Galli, E. \& Barbieri, P. (1995). Cloning and comparison of mercury- and organomercurial-resistance determinants from a Pseudomonas stutzeri plasmid. Gene 166, 77-82.

Roberts, M. S. \& Cohan, F. M. (1995). Recombination and migration rates in natural populations of Bacillus subtilis and Bacillus mojavensis. Evolution 49, 1081-1094. 
Robinson, J. B. \& Tuovinen, O. H. (1984). Mechanisms of microbial resistance and detoxification of mercury and organomercury compounds: physiological, biochemical and genetic analyses. Microbiol Rev 48, 95-124.

Sambrook, J., Fritsch, E. F. \& Maniatis, T. (1989). Molecular Cloning: a Laboratory Manual, 2nd edn. Cold Spring Harbor, NY: Cold Spring Harbor Laboratory.

Sanger, F., Nicklen, S. \& Coulson, A. R. (1977). DNA sequencing with chain-terminating inhibitors. Proc Natl Acad Sci USA 74, 5463-5467.

Sedlmeier, R. \& Altenbuchner, J. (1992). Cloning and DNA sequence analysis of the mercury resistance genes of Streptomyces lividans. Mol Gen Genet 236, 76-85.

Shiratori, T., Inoue, C., Sugawara, K., Kusano, T. \& Kitigawa, Y. (1989). Cloning and expression of Thiobacillus ferrooxidans mercury ion resistance genes in Escherichia coli. J Bacteriol 171, 3458-3464.

Siemieniak, D. R., Slightom, J. L. \& Chung, S. T. (1990). Nucleotide sequence of Streptomyces fradiae transposable element Tn4556: a class II transposon related to Tn3. Gene 86, 1-9.

Silver, S. \& Phung، L. T. (1996). Bacterial heavy metal resistance: new surprises. Annu Rev Microbiol 50, 753-789.

Summers, A. O. (1986). Organization, expression and evolution of genes for mercury resistance. Annu Review Microbiol 40, $607-634$.

Van de Peer, Y. \& De Wachter, R. (1994). TREecon for Windows: a software package for the construction and drawing of evol- utionary trees for the Microsoft Windows environment. Comput Appl Biosci 10, 569-570.

Wang, Y., Mahler, I., Levinson, H. S. \& Hallorson, H. O. (1987). Cloning and expression in Escherichia coli of chromosomal mercury resistance genes from a Bacillus sp. J Bacteriol 169, $4848-4851$.

Wang, Y., Moore, M., Levinson, H. S., Silver, S., Walsh, C. \& Mahler, I. (1989). Nucleotide sequence of a chromosomal mercury resistance determinant from a Bacillus $s p$. with broad-spectrum mercury resistance. J Bacteriol 171, 83-92.

Witte, W., Green, L., Misra, T. K. \& Silver, S. (1986). Resistance to mercury and to cadmium in chromosomally resistant Stapbylococcus aureus. Antimicrob Agents Chemother 29, 663-669.

Yurieva, O. \& Nikiforov, V. (1996). Catalytic center quest: comparison of transposases belonging to the $\operatorname{Tn} 3$ family reveals an invariant triad of acidic amino acid residues. Biochem $\mathrm{Mol}$ Biol Int 38, 15-20.

Yurieva, O. V., Kholodii, G. Ya., Minakhin, L. S., Gorlenko, Zh. M., Kalyaeva, E. S., Mindlin, S. Z. \& Nikiforov, V. G. (1997). Intercontinental spread of promiscuous mercury resistance operons in environmental bacteria. Mol Microbiol 24, 321-329.

Zharkikh, A. A., Rzhetsky, A. Yu., Morosov, P. S., Sitnikova, T. L. \& Krushkal, J. S. (1991). vostoRG: a package of microcomputer programs for sequence analysis and construction on phylogenetic trees. Gene 101, 251-254.

Received 8 July 1997; revised 16 October 1997; accepted 12 November 1997. 